\title{
MEMBACA KOMIK CRAYON SHINCHAN \\ DENGAN WACANA POSMODERNISME
}

\author{
oleh Widyastuti Purbani \\ FBS Universitas Negeri Yogyakarta
}

\begin{abstract}
This article is concerned with a heated controversy about the Crayon Synchan comic serial and aims at producing an alternative reading view using a postmodern perspective. Situating the text concerned in the discourse of postmodernism, referring especially to its view on the fall of grand narratives, the use of parody and intertextuality, the way it posits readers, the aestheticization of ordinary life, and the way it sees the human body and sexuality, we could render more understanding and fair value judgment and therefore restrain our prejudice towards this text.
\end{abstract}

Keywords: postmodernism, metanarrative, parody

\section{A. PENDAHULUAN}

Meskipun sudah dimulai sejak tahun 2001, kontroversi seputar komik Crayon Shinchan tidak kunjung reda hingga kini. Sebagian besar orang masih menganggap teks ini sebagai bacaan kotor bagi anak-anak, dan oleh karenanya patut dihindari. Ketika komik dan tayangan film Shinchan mulai populer, protes dilakukan secara bertubi-tubi tidak hanya oleh para orang tua, tokoh masyarakat, guru tapi juga oleh para ilmuwan, dan pejabat pemerintahan. Sejak tahun 2001 Kepala Dinas Pendidikan dan Pengajaran Kabupaten Sleman, DIY mengeluarkan surat edaran kepada sekitar 560 sekolah di bawah tanggung jawabnya, yang isinya melarang para siswa asuhannya membaca komik Crayon Shinchan. Beberapa sekolah lain misalnya SD Islam Harapan, Jakarta juga melarang siswanya membaca Crayon Shinchan. Murti Bunanta, pakar Sastra Anak Universitas Indonesia, menyatakan bahwa komik Crayon Shinchan parah, dan tidak pas bagi anak-anak. Bersama beberapa penulis artikel lainnya ia menyatakan kepada masyarakat luas melalui berbagai surat kabar bahwa komik Crayon Shinchan berbahaya bagi anak-anak dan oleh karenanya anak-anak harus dilindungi dari bacaan tersebut (Gamma,
Januari 2001). Yayasan Lembaga Konsumen Indonesia menerima banyak protes dan himbauan dari para orang tua untuk melindungi anak-anak mereka dari pengaruh buruk bacaan komik pada umumnya, dan Crayon Shinchan pada khususnya. Seto Mulyadi, psikolog dan pemerhati anak, menyatakan dengan tegas bahwa Shinchan tidak tepat dan efeknya jelek bagi anak-anak, karena kata-katanya vulgar dan mengandung unsur pornografi (Gamma, Januari 2001). Banyak seminar dilakukan dan artikel ditulis yang isinya rata-rata menyimpulkan bahwa komik ini perlu diwaspadai karena mengandung pornografi dan pikiran-pikiran yang tidak tepat dikonsumsi oleh anak-anak (Suherman, 2002). Komik yang diciptakan dengan gaya kartun ini telah menjadi teror dan ancaman yang dikhawatirkan membawa pengaruh buruk bagi anak-anak dan remaja Indonesia.

Di lain pihak, komik ini tetap merebut hati anak-anak dan remaja. Toko-toko buku besar seperti Gramedia mengaku omzet penjualan komik ini termasuk lebih tinggi dibanding bacaan anak yang lain. Menurut Lunardi, Kepala TB Gramedia Bandung, dalam seminggu saja lebih kurang 1000 komik Crayon Shinchan laku terjual (Gamma, Januari 2001). 
Tayangan film Shinchan di televisi menduduki rating yang tinggi, dan menerima himbauan untuk menambah jam tayang. Taman-taman bacaan yang mengoleksi komik Shinchan mengaku bahwa teks tersebut termasuk yang paling digemari pelanggannya. Beberapa anak mengaku tetap membaca komik Shinchan meskipun dilarang orang tua atau guru mereka, karena mereka terlanjur menyukai tokohtokohnya (Sadar dkk., 2003). Joshua Suherman, artis cilik Indonesia mengaku menyukai komik tersebut karena walaupun nakal dan sedikit porno tetapi bagus, lucu dan ceritanya masuk akal (Gamma, Januari 2001). Sampai sekarang komik yang telah mencapai 30 volume ini tetap dibaca dan beredar, dan filmnya tetap ditayangkan pada hari Minggu atau hari libur anak-anak, sementara orang tua, guru atau para tokoh masyarakat tetap melarang anak-anak mereka mengkonsumi teks ini.

Mengapa teks, khususnya komik Crayon Shinchan ini dibenci sekaligus disukai, dianggap 'sampah' sekaligus 'gula-gula', dihindari sekaligus dirindukan? Menggunakan wacana postmodernisme, tulisan ini hendak mengkaji mengapa kontroversi seperti ini terjadi, dan bagaimana masyarakat Indonesia harus menyikapinya.

\section{B. KOMIK CRAYON SHINCHAN, JATUHNYA NARASI BESAR, DAN KEKABURAN BATAS}

Postmodernisme ditandai dengan jatuhnya pamor metanarrative, atau teks-teks besar seperti kitab-kitab suci, wacana Marxisme, karya-karya kanon ciptaan pujangga-pujangga besar yang dulu diagungkan. Di sisi lain, teks-teks kecil yang dulu dipinggirkan atau dianggap tidak penting mulai bangkit dan merebut posisi yang baik. Suara yang secara historis terpendam oleh kebesaran teks-teks agung, bangkit dan menemukan dirinya kembali. Atau seperti yang dikatakan Francois Lyotard, postmodernisme ditandai dengan runtuhnya narasi-narasi besar yang bersifat universal dengan segenap hakhak istimewanya untuk mengatakan kebenaran. Sebagai gantinya kita akan menyaksikan semakin nyaringnya berbagai ragam suarasuara dari pinggiran, dengan segenap perbedaan dan keanekaan budaya.

Dalam pandangan kaum modernis, komik merupakan teks marjinal yang dianggap dangkal, baik dari segi artistik maupun filosofinya. Teks ini jarang atau tidak diperhitungkan sebagai karya yang baik, dan bahkan sering dianggap sebagai sampah belaka. Anak-anak atau remaja dilarang membaca komik, karena dikhawatirkan akan mengalami pendangkalan pikiran. Para elit modern merasa harus mempertahankan supremasi dan modal budayanya dari serangan teks-teks baru, yang 'dibuat ala kadarnya', yang mereka anggap akan meracuni generasi muda mereka. Bertahuntahun komik terkubur di antara 'kebesaran' teksteks seperti cerita rakyat, dongeng, novel, puisi yang dianggap 'lebih mendidik' dan lebih 'sesuai dengan budaya bangsa'. Jarang sekali kita menjumpai perpustakaan sekolah atau perpustakaan instansi formal yang mengoleksi komik. Membaca komik, kemudian sering harus dilakukan secara sembunyi-sembunyi karena jika diketahui orang tua atau guru akan dianggap sebagai pelanggaran. Dalam pandangan modern, novel atau puisi karya penulis-penulis terkenal lah yang dianggap memiliki nilai dan dianjurkan untuk dibaca. Ketidaksukaan para elite modernis terhadap komik Crayon Shinchan kemungkinan besar juga dipengaruhi oleh antipati mereka terhadap komik yang dalam kategori mereka termasuk teks-teks sampah. Teks seperti in ditakutkan akan meracuni generasi muda yang merupakan aset bangsa.

Tapi rupanya ketakutan dan usahausaha pertahanan kaum elit modern ini tidak mampu membendung bangkitnya teks-teks 'sampah' seperti ini, karena pada era postmodern ini hirarki 'bacaan tinggi' versus 'bacaan rendah' telah luruh. Banyak bukti yang menunjukkan lunturnya popularitas dan kemegahan teks-teks yang dulu dianggap sebagai karya kanon seperti karya-karya Shakespeare, dan justru naiknya pamor teksteks populer, seperti Shopie's World, atau Harry Potter. Di mata Wheale, hirarki-hirarki budaya 
tinggi-budaya rendah, budaya elite-budaya massa telah luruh dan pudar di era postmodernisme:

Postmodernism is often described as blurring or destroying distinctions between established cultural hierarchies, and it said to do this by intoducing themes and images from mass/popular/consumer culture into the prestige forms of high culture, such as literature and the fine arts. The terms in which 'the cultural' is described here high against low, mass against elite, consumer-popular as opposed to educated are not value free, but are intrinsic to the debate (Wheale, 1995: 34).

Era Shinchan adalah jaman di mana komik semakin diminati dan kepopulerannya mengalahkan teks-teks yang dahulu diagungkan. Taman-taman bacaan yang berkembang secara informal di kalangan masyarakat, justru menempatkan komik sebagai koleksi utama, karena mendapati bahwa jenis bacaan ini lebih banyak dicari oleh pelanggan dibandingkan dengan novel, dongeng atau cerita rakyat (Sadar, 2003). Orang juga tidak malu-malu atau takut-takut lagi membaca komik di tempat umum. Komik bahkan mulai diteliti dan dipelajari secara serius di berbagai sekolah seni atau sastra. Buku-buku tentang komik ditulis untuk dijadikan acuan. Beberapa karya-karya 'serius' dan 'besar' seperti buku tentang Derrida, atau Cultural Studies, yang bersifat formal dan akademik bahkan ditulis dalam bentuk komik. Komik tidak lagi menjadi teks pinggiran.

Komik Shinchan diciptakan oleh Yoshito Usui, seorang pekomik Jepang. Teks ini bercerita tentang kehidupan seorang anak dari sebuah keluarga Jepang. Beberapa ciri khas yang merupakan nilai lokal Jepang tetap dipertahankan dalam komik ini, seperti tampak pada nama orang, makanan khas, serta beberapa kebiasaan tertentu seperti mandi bersama, tidur di lantai. Tetapi identitas Jepang tersebut tidak terlalu mengganggu pemahaman pembaca global, dan justru memberi referensi mengenai suara budaya lain yang mendukung wacana multikulturalisme. Kekhasan lokal Jepang kemungkinan sengaja dieliminir dengan menggunakan gambar tokoh Shinchan dalam bentuk kartun yang simpel, ikonik, subyektif dan dengan demikian mendapatkan sifat yang lebih universal jika dibandingkan dengan bentuk realistik yang kompleks dan oleh karenanya spesifik (McCloud, 1993:46). Itulah mengapa komik ini dengan mudah diterima dan bahkan digemari di mana-mana, termasuk Korea, Taiwan, China, Malaysia, Hongkong, Thailand, Spanyol dan di Indonesia tanpa ada kendala budaya yang berarti. Komik Shinchan mampu menembus batas-batas geografis dan budaya sebagai akibat dari fasilitas teknologi yang canggih baik dalam hal penciptaan maupun distribusinya. Misalnya, untuk peredaran di Indonesia komik ini sekarang tidak harus diproduksi dan diterjemahkan di Jepang, tetapi di Jakarta.

Kemungkinan besar akibat pengaruh perkembangan teknologi dan media, khususnya semakin besarnya peran televisi, film dan internet dalam kehidupan manusia, era postmodern adalah era melihat/menonton dan bukan lagi disebut era membaca. Kegiatan yang bersifat visual dengan menggunakan gambar menjadi obsesi, dan membaca mulai ditinggalkan. Buku-buku masa kini menggunakan banyak ilustrasi visual baik berupa foto, gambar, grafik, sketsa dsb. yang dianggap mampu mengatakan jauh lebih banyak makna daripada deskripsi tertulis/naratif. Buku cerita bergambar, bahkan wordless picture books atau buku cerita minim kata-kata lebih populer di kalangan anak-anak sekarang. Iklan-iklan di media cetak menggunakan jauh lebih banyak visualisasi daripada kata-kata. Pembicara dalam seminarseminar akademik lebih disibukkan dengan presentasi visual daripada menulis makalahmakalah yang panjang. Bagi Wheale, kita sekarang lebih responsif terhadap citraan visual daripada terhadap tulisan seiring dengan lunturnya kebiasaan membaca: 
the distracting, invasive effects of media culture are said to make us more responsive to visual imagery than to writing; the habit of reading is in decline, whether texts are newspapers, novels, poetry or children's fiction. Television, video and films all distract from the page; in advertising the visual image now predominates over written copy, where until the 1940s the picture served the text (Wheale, 1995: 53).

Komik merupakan teks di mana gambar lebih dominan daripada narasi. Ketidaktelatenan orang atau anak-anak untuk membaca narasi-narasi panjang, akibat pendeknya periode konsentrasi yang dimiliki manusia visual inilah yang barangkali telah menyebabkan lebih digemarinya komik daripada novel atau teks naratif yang lain. Ini pulalah yang barangkali telah membuat para elit modern merasa bahwa generasi muda kita terancam, karena dalam pemikiran mereka kebiasaan membaca masih dianggap penting baik pada masa sekarang maupun pada masamasa yang akan datang.

Dalam kategorisasi teks menurut pandangan modern, novel, puisi, cerita, komik adalah rekaan (fiksi). Tapi fiksi memiliki beberapa genre dan sub genre, yang salah satunya ditentukan oleh seberapa dekat ia dengan realitas, misalnya ada genre realisme, ada genre fantasi dan bahkan high fantasy. Dalam genre komik sendiri, ada sub genre komik realis dan ada pula sub genre non realis. Crayon Shinchan termasuk dalam kategori/sub genre non realis. Sifat coretannya yang lebih mendekati kartun semakin menipiskan tingkat realismenya. Tapi semua ini menjadi tidak relevan lagi manakala kita memandang komik menggunakan kacamata postmodernisme, yang menyetujui pandangan Baudrillard, seperti diungkapkan Barker sbb:

Baudrillard's world is one in which a series of modern distictions have broken down (sucked into a 'black hole', as he calls it), collapsing the real and the unreal, the public and the private, art and reality. For Baudrillard, postmodern culture is marked by an all-encompassing flow of fascinating simulations and image, a hyperreality in which we are overloaded with images and information: It is reality itself today that is hyperrealist...it is quotidian reality in its entirety political, social, historical and economic that from now on incorporates the stimulating dimension of hyperrealism. We live everywhere in an 'aesthetic' hallusination of reality' (Baudrillard dalam Barker, 2000:158).

Menurut Baudrillard, kecuali terjadinya the blurred genres atau pembauran kategorisasi, pembedaan antara riil dan tidak riil pun sudah pudar. Menurutnya budaya postmodernisme ditandai dengan arus besar simulasi dan citraan. Dunia kita merupakan dunia hiper-realitas, di mana realitas sudah menjadi sekadar halusinasi akibat banjirnya imaji, citraan dan informasi dalam segala bidang kehidupan. Itulah sebabnya komik yang jelas-jeas tidak riil, yang merupakan simulasi bersifat kartunis pun mampu menggerakkan dan mempengaruhi kehidupan. Pengaruh teks semaya komik bahkan bisa jauh lebih besar daripada pengaruh sejarah, yang tingkat realismenya jauh lebih tinggi.

Hirarki bahwa teks-teks realis memiliki kadar kepercayaan lebih besar daripada teks-teks non realis semacam komik Crayon Shinchan ini menjadi tidak relevan pada era postmodernisme ini, karena orang sudah tidak memilah-milahkan lagi mana yang realis, mana yang tidak. Orang sudah tersedot masuk ke dalam lubang hitam di mana yang riil dan yang tidak riil tidak tampak jelas.

Kekaburan batas juga muncul pada pembaca Crayon Shinchan. Beberapa sumber menyatakan bahwa teks ini pada awalnya ditujukan kepada kaum dewasa, tetapi pada kenyataannya komik ini digemari pula oleh anak-anak (Gamma, Januari 2001). Era postmodern adalah era yang telah 
meninggalkan orientasi penulis (writerly) untuk menuju era pembaca (readerly) dengan the death of the author, matinya sang penulis (Barthes, 1977:115-117). Kini fokusnya tidak lagi pada karya atau pengarang, melainkan pada penafsir, pembaca atau penikmat karya (Lubis, 2004:103).

\section{PEMBACA (AKTIF) CRAYON SHINCHAN}

Pernyataan bahwa komik Crayon Shinchan pada awalnya ditujukan untuk pembaca dewasa diungkapkan berdasarkan pandangan berorientasi writerly bahwa penulis atau karya mampu dan memiliki kewenangan menentukan siapa pembacanya. Ini merupakan manifestasi intentional fallacy, yakni bahwa intensi penulis bisa salah. Jika pada kenyataannya Shinchan justru diminati oleh banyak pembaca anak, adalah manifestasi dari konsep bahwa pembacalah yang berkuasa menentukan makna teks. Sehingga label bertuliskan "Untuk 15 tahun ke atas", seperti yang dituntut oleh banyak pakar anak, yang dicantumkan pada cover komik Crayon Shinchan, menjadi kurang relevan lagi, karena pada kenyataannya komik ini tetap dibaca oleh anak-anak. Kekuasaan kini ada pada pembaca.

Di samping itu menurut McRobbie (1994), pembaca postmodern bukanlah kumpulan orang-orang yang berpikiran sempit, yang mudah diombang-ambingkan oleh teks. Seperti yang ditegaskan pula oleh Barker (2000: 269) yang menyatakan bahwa pembaca/penonton sebenarnya merupakan pencipta makna yang aktif terhadap tontonan atau bacaan. Mereka tidak begitu saja menerima makna teks tanpa berpikir panjang. Mereka melakukannya berdasarkan makna budaya yang telah didapatkannya sebelumnya dalam konteks bahasa dan relasi sosial di mana mereka berada.

Jika kita bersetuju dengan apa yang dikemukakan oleh beberapa pemerhati seperti tersebut di atas, maka kekhawatiran bahwa pembaca Crayon Shinchan akan tersesat atau menjadi korban kekotoran teks menjadi kurang relevan. Dari komentar-komentarnya kepada
Gamma (2001) tersirat bahwa para pembaca anak-anak pun melakukan negosiasi makna, dan tidak terlarut dalam dominasi teks.

\section{CRAYON SHINCHAN DALAM KONTEKS KONSUMSI DAN IDENTITAS POSTMODERNISME}

Postmodern adalah masa di mana kegiatan mengkonsumsi dilakukan bukan hanya sekadar untuk menikmati guna atau fungsi dari suatu barang, tetapi untuk menemukan identitas konsumen. Manusia postmodern berada pada jaman di mana orang tidak lagi membeli suatu barang karena didorong oleh kegunaan barang tersebut, tetapi lebih dipengaruhi oleh pengaruh benda tersebut terhadap hubungan mereka dengan tatanan sosial di mana mereka hidup atau berada. Anakanak atau remaja barangkali tidak membeli atau membaca komik Crayon Shinchan sematamata karena merasa isi/bacaan komik tersebut memiliki manfaat langsung bagi mereka, tetapi karena anak-anak atau remaja di sekitar mereka membicarakan tentangnya, dan jika mereka tidak tahu menahu tentang bacaan itu mereka akan dianggap ketinggalan jaman atau bukan termasuk komunitas tersebut. Inilah yang terjadi pada Asep, Vikra dan banyak anak yang lain, seperti yang dituturkan pada Gamma (Januari 2001). Konsumsi mereka atas komik bisa jadi lebih didorong oleh kinship, comradery atau hubungan mereka dengan anggota komunitas di mana mereka merasa menjadi anggotanya. Dalam hal ini, Sarup menyatakan bahwa konsumsi tidak lagi perlu diartikan sebagai konsumsi tehadap nilai guna suatu barang atau jasa, tetapi lebih dari itu adalah konsumsi terhadap tanda-tanda. Orangorang mencari tempat dan tatanan (identitas) melalui objek-objek yang mereka konsumsi. Fungsi dari komoditas tidak lagi untuk memenuhi kebutuhan seseorang, tetapi juga dalam kaitannya dengan tatanan sosial. Dengan kata lain, konsumsi berfungsi membentuk cita rasa diri:

Consumption, then must not be understood as the consumption of usevalues, but primarily as the 
consumption of signs. Baudrillard believes that it is through objects that each individual searches out his or her place in an order. The function of commodities, then, is not just to meet individual needs, but also to relate the individual to the social order. Consumption is not just the end point of the economic chain that began with production, but a system of exchange, a language in which commodities are goods to think with in a semiotic system that precedes the individual, as does any language. For Baudrillard there is no self-contained individual, there are only ways of using social systems, particularly those of language, goods and kinship, to relate people differently to the social order and thus to construct the sense of the individual (Sarup, 1993:162).

Tampaknya identitas yang direpresentasikan oleh komik Shinchan adalah identitas 'bad kid' atau naughty kid: anak yang bengal, nakal, bandel. Ini bisa dilihat dari citra yang dibangun lewat cover-cover komik itu sendiri serta ikon-ikon yang diciptakan mengenai Shinchan, baik yang berupa stiker, gantungan kunci, boneka, mainan, ilustrasi kaos/pakaian, poster, cover buku atau alat tulis dsb.

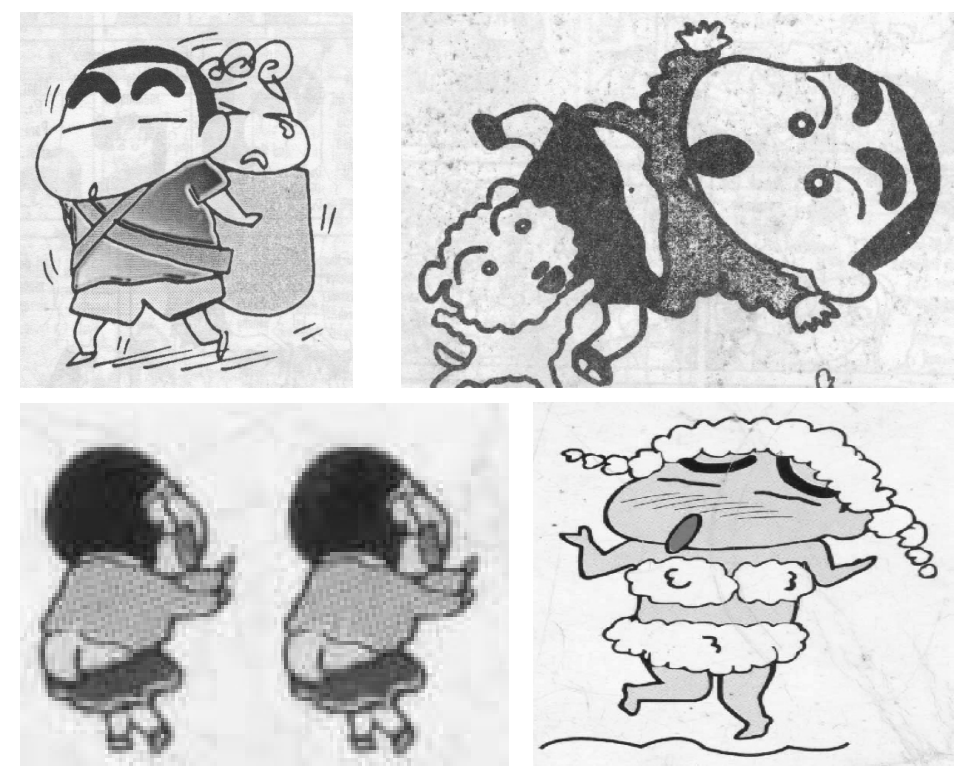

Shinchan sering digambarkan memelorotkan celananya sampai pantatnya kelihatan, mengenakan sebagai kacamata/ bermain-main dengan bra ibunya, bermainmain dan menempelkan busa sabun mandi di dada dan bagian bawah perutnya hingga menyerupai perempuan berbikini, mengendarai sepeda dengan kencang hingga hampir jatuh, atau bersembunyi di balik anjing yang sedang berjalan. Wajah Shincan selalu digambarkan inosen, mulut melongo, mata terbelalak, yakni identitas 'bad boy' yang sedikit tolol, yang ingin melawan dominasi citra anak yang baik (goody kid) yang biasanya dibangun oleh buku-buku cerita anak pada umumnya. Walaupun dalam kadarnya yang kecil, ada unsur kitsch (benda atau barang sampah) atau camp (sikap atau suara marginal yang kampungan) yang dibangun dalam teks ini, khususnya pada watak tokoh Shinchan.

Tumbuhnya wacana 'bad kid' ini juga merupakan runtuhnya nilai-nilai lama mengenani 'anak yang baik' dalam cerita. 'Baik' dalam pengertian sekarang adalah nilai yang melekat pada nilai 'cool', yang dapat mengandung unsur bad, atau nakal/naughty. Jadi nilai 'baik' yang tumbuh sekarang 
mengandung beberapa unsur yang dulu justru dimaknai secara negatif, yakni nakal, bengal, yang ada pada diri Shinchan dalam komik ini. Lagu Shinchan yang diputar menjelang dan sesudah filmnya mendukung terbangunya image ini:

Seluruh kota, merupakan tempat bermain gembira

Sang gajah, terserang flu, pilek tiada henti-hentinya

Sang beruang tidur dan tak ada yang berani ganggu dia

Oh sibuknya, aku sibuk sekali!

Penggal lagu yang merupakan hit dari film Shinchan ini menggambarkan Shinchan sebagai anak yang gembira, suka bermain, dan bagi dia, dunia (seluruh kota) ini terbuka untuk dijadikan arena permainan. Sementara kedua orang tuanya (yang dia sebut secara nakal sebagai gajah dan beruang) asyik sendiri dengan kegiatan mereka (sakit flu dan tidur), sementara ia, bak seorang bisnisman, sibuk sekali (tentu dengan ullahnya). Ia digambarkan sebagai anak yang aktif, tidak suka diam (sibuk). Dari lagu itu juga tersirat makna bahwa Shinchan menjadi nakal (sibuk) karena kurangnya perhatian kedua orang tuanya kepadanya.

Anak-anak dan remaja yang telah jenuh dengan konstruksi anak yang baik dan soleh, seperti yang biasa dicitrakan dalam bacaanbacaan dan dongeng formal mereka, akan mendapatkan alternatif lain dalam teks komik Crayon Shinchan ini. Apalagi bagi mereka yang konsep anak baik/soleh selama itu disampaikan secara didaktis/mencekoki melalui teks-teks yang mereka baca, komik Shinchan sekaligus akan merupakan media resistansi bagi mereka, untuk secara implisit menolak ajaran formal yang bersifat menggurui tersebut.

\section{E. CRAYON SHINCHAN DAN 'THE AESTHETICIZATION OF ORDINARY LIFE' $^{\prime}$}

Komik Shinchan menceritakan kehidupan sehari hari. Ia tidak bercerita mengenai pahlawan pemberani yang menjadi penyelamat masyarakat seperti Superman atau Pahlawan Bertopeng yang secara ironis sering diacu. Teks ini lebih tertarik untuk mengungkap hal-hal 'sepele' yang merupakan pengalaman sehari-hari seorang anak bersama keluarga dan orang-orang di sekitarnya seperti teman bermain, guru, tetangga. Episode-episode Shinchan adalah untaian cerita mengenai kegiatan mencuci mobil, memasak bekal untuk piknik, latihan cebok, main petak umpet, latihan kumur-kumur, membeli ubi untuk Mama, 'mengasuh' Shiro dsb. yang jelas-jelas bukan merupakan isu yang sensasional dan dramatis dalam kehidupan manusia. Tetapi cerita dan isu-isu keseharian tersebut dalam pandangan postmodernisme justru merupakan persoalan yang penting, karena menyangkut ordinary lives yang lebih menyentuh nilai-nilai humanisme. Figur-figur postmodernisme adalah figur-figur yang berasal dari kehidupan sehari-hari, yang menceritakan mengenai pandangan-pandangan dan hasrat mereka untuk menjadi objek budaya. Seperti kita ketahui selama ini pemahaman tentang budaya tidak atau kurang menyentuh hal-hal yang sepele atau hal yang biasa dalam kehidupan:

.....the postmodern figural is more visual, draws from everyday life, contests rationalist views of culture and immerses the spectator in his/her desire for the cultural object. The increasing prominence of the postmodern figural is integral to the aestheticization of everyday life and to the erosion of the cultural boundaries of modernity. The blurring of the bounderies between art and culture, culture and commerce, allied to the prominence of the image, have arguably resulted in an aetheticization of urban life (Featherstone dalam Barker, 2000: 155).

Cerita Crayon Shinchan adalah cerita keseharian yang sepele, tapi jika direnungkan dapat merupakan hal yang serius. Dalam episode 'Membeli Ubi Goreng' (Vol 2, 1993:8284) yang menceritakan Mama menyuruh 
Shinchan membelikan ubi goreng yang dijajakan di depan rumah mereka, misalnya, alasan Mama menyuruh Shinchan, dengan repot-repot 'menyuap' Shinchan dengan jus apel, adalah karena ia tidak ingin diketahui tetangga bahwa seleranya rendah (suka ubi). Rupanya Shinchan mengetahui kemunafikan Mama ini sehingga justru mempermainkannya dengan pura-pura tidak bisa, mengulur-ulur waktu atau meminta sogokan yang lebih, hingga Mama marah sekali. Dari kejadian sepele dan lucu ini teks mengungkap persoalan yang lebih serius, yakni kemunafikan orang tua, yang dapat secara gamblang dibaca oleh anak sekecil Shinchan.

.....blended together in a way which was sometimes to be taken seriously and at other times regarded as humorously ambivalent parody. This was accompanied by a series of tonal variations including pathos and camp, seriousness and humour which encourages the shifting of subject position and oscillation of emotional involvement in one series that a strip text might create across an evening (Collins dalam Barker: 156).

Dalam satu episode, subject position pembaca dapat terombang-ambing oleh permainan antara keseriusan dan kekonyolan/kekocakan teks.

\section{F. I R O N I , P A R O D I D A N INTERTEKSTUALITAS DALAM CRAYONSHINCHAN}

Teks Crayon Shinchan disajikan dalam bentuk parodi dan ironi tentang kehidupan. Parodi yang memiliki arti 'bernyanyi di sampingnya', pada mulanya dimaknai 'mengkopi suatu teks orisinil dengan cara memutarbalikkan atau memperolokkannya', tapi pada perkembangannya kemudian, parodi lebih diartikan sebagai perolok-olokan dengan cara yang karikatural, lucu tapi sekaligus cerdas misalnya dengan cara pelebih-lebihan sifat justru untuk mendistorsi makna. Sedangkan ironi merupakan ungkapan yang secara sengaja diekspresikan terselubung tentang sesuatu hal yang bermakna sebaliknya.

Parodi yang terjadi dalam Crayon Shinchan adalah pemutarbalikan teks-teks klasik tentang anak-anak, yang biasanya menempatkan anak-anak sebagai karakter yang baik sekalipun kebaikan tersebut harus dicapai melalui proses. Tokoh-tokoh anak klasik (Rapunzel, Red Little Riding Hood, The Ugly Duckling) adalah anak yang mau belajar dari pengalaman-penagalaman, yang mendengarkan nasehat orang tua, yang tekun dan bekerja keras. Itulah sebabnya tokoh-tokoh pada cerita anak klasik mengalami proses pembelajaran dan mendapatkan hikmah kebahagiaan dari usaha mereka.

Shinchan, tokoh utama komik postmodern ini adalah yang sebaliknya dari semua itu. Oleh Shinchan, pengalamanpengalaman sering dimaknai sebaliknya, misalnya permainan Cilukba yang diajarkan Papa, ia lakukan dengan membuka dan menutup tubuh telanjangnya dengan handuk di hadapan gadis yang lewat. Nasehat orang tua sering diinterpretasikan secara keliru, misalnya nasehat untuk rajin memberi makan anjing Shiro, ia lakukan dengan memberikan makanan yang enak-enak dengan menggunakan piring mahal kesayangan Mama. Shinchan bahkan sering balik menasehati orang tua mereka, misalnya ketika mereka berbelanja di supermarket yang padat, Shinchan menasehati Papa untuk berhati-hati supaya tidak tersesat. Ketika Shinchan tersesat di supermarket, ia malah melapor ke bagian anak hilang bahwa mamanya telah hilang: "Ibuku hilang, apa kau tahu di mana dia?", dan ketika petugas bertanya siapa nama Shinchan, Shinchan balik bertanya: "Sebelum bertanya pada orang lain, sebutkan nama dirimu sendiri, begitu kata guru Yoshinaga" (Vol. 4 : 99). Dan ketabahan yang telah diusahakan oleh Shinchan justru menghasilkan petaka atau kecelakaan yang memalukan, misalnya ketika ia bersusah payah memandikan Shiro, ia memasukkan seluruh parfum mandi mahal jatah sebulan ke dalam bak mandi sehingga dihukum Mama; atau ketika ia belajar cebok di toilet, ia gunakan seluruh tissue yang ada sehingga toilet penuh 
dengan timbunan tissue. Ketika Shinchan berusaha membantu ayahnya mencuci mobil dan melihat ada noda di sisi mobil, ia gunakan pasak besi untuk membersihkan noktah tersebut hingga cat mobil lecet-lecet (Vol. 4).

Pemutarbalikan dan perolok-olokan konsep modernis orang tua yang berwibawa dan bijaksana juga terjadi pada teks Crayon Shinchan. Kedua orang tua Shinchan merupakan tokoh-tokoh yang, meskipun penyayang dan baik hati, memiliki banyak kelemahan/flaws. Mama Shinchan merupakan tokoh yang mudah marah, tidak jera memukul Shinchan yang bandel, cerewet; sedangkan ayah adalah figur yang pelupa, pemalas dan suka menggoda wanita. Mereka bahkan banyak belajar dari Shinchan.

Seperti disebutkan di atas, konsep eklektisme dan intertekstualitas, yang menjadi ciri khas teks-teks postmodern juga muncul dalam Crayon Shinchan. Teks ini sering menggunakan teks-teks lain yang sudah dikenal baik, terutama oleh anak-anak dan remaja, sebagai referensi, kadang-kadang sebagai media untuk ironi atau piranti intensifikasi makna. Misalnya ketika Shinchan dan keluarganya sedang makan malam, anak ini justru asyik menonton film di TV, sehingga Mama marah-marah karena suasana makan menjadi tidak nyaman. Kemarahan Mama yang dilakukan dengan menggebrak-gebrak meja diasosiasikan secara intertekstual dengan tokoh Superman pada film TV yang pada saat yang sama sedang ditonton oleh Shinchan. Beberapa kali ketika ada 'musuh' mengganggu di rumah, seperti kecoa atau ular kecil, Shinchan selalu menggunakan kostumnya, berlagak seperti pahlawan bertopeng dari film kesukaannya dan berusaha 'menyelamatkan' keluarganya. Teks ini sekaligus memperolok teks-teks lama yang terlalu mengangungkan kepahlawanan atau kepeloporan. Teks-teks postmodernime, menurut Lubis (2004:17) adalah teks yang miskin kepeloporan.

Secara intertekstual dongeng-dongeng atau cerita klasik seperti Putri Salju, Tiga Ekor Anak Babi, Kelinci dan Kura-Kura sering digunakan untuk mengintensifikasi makna teks, misalnya ketika Mama Shinchan marah-marah karena hal sepele, Shinchan berfantasi bahwa itu bukan Mamanya yang asli, dan bahwa Mama yang sebenarnya adalah seorang Putri Salju yang cantik jelita dan baik hati. Tetapi ketika melihat salah satu kelemahan Putri Salju, Shinchan segera sadar bahwa Mamanya sendiri jauh lebih baik. Pada episode lain Shinchan berfantasi menjadi kura-kura dalam cerita Kelinci dan Kura-Kura dan memenangkan lomba balap yang diselenggarakan kelincikelinci licik yang mencoba menculik teman sekolah Shinchan (Vol 18, 71-81).

\section{G. $C R A Y O N \quad S H I N C H A N$ DA N PANDANGAN POSTMODERNISME TENTANG SEKSUALITAS}

Era postmodernime merupakan era ditanggalkannya selubung-selubung yang selama ini dianggap menjerat atau mengekang kebebasan, sehingga merugikan individu. Salah satu di antaranya adalah kebebasan berekspresi seksual, yang selama ini dianggap tabu dan pantang untuk diungkapkan. Para pemikir postmodernisme dekonstruktif mengembangkan wacana tubuh dan hasrat yang baru, dalam rangka mendobrak berbagai benteng, tembok dan tapal batas, yang selama ini membatasi artikulasi dan pelepasan hasrat; menghancurkan berbagai bentuk kekuasaan (power), baik itu kekuasaan dalam keluarga, negara, agama; mencerai-beraikan otoritas atau hegemoni yang selama ini membatasi eksploitasi tubuh, dengan berbagai potensi dan peluang eksplorasinya (Piliang, 2004:385).

Menurut Foucault (1997 : 1-3), yang merupakan salah satu pemikir postmodernis, rezim yang angkuh dan munafik telah lama melakukan represi-represi terhadap hasrat dan seksualitas. Seksualitas telah lama dipingit rapi dirumahtanggakan, dan dibenamkan dalam fungsi reproduksi semata, hingga orang tidak berani dan mampu lagi berkata apa pun mengenainya. Seks telah lama diusir, disangkal dan ditumpas sampai hanya kebungkaman yang tersisa. Seksualitas bukan hanya tidak ada, melainkan tidak boleh hadir dan segera ditumpas begitu tampil dalam tindak atau 
wicara. Anak-anak dianggap tidak mempunyai seks, oleh sebab itu mereka lebih baik ditabukan, dilarang membicarakannya. Mata mereka mesti ditutup, telinga mereka mesti disumbat, mulut mereka mesti dibungkam secara menyeluruh dan patuh.

Teks Shinchan dilarang dan dihujat karena dianggap mengandung pornografi. Piliang mendefinisikan pornografi sebagai 'representasi (dalam literatur, film, video, drama, seni rupa dsb.) yang tujuannya adalah untuk menghasilkan kepuasan seksual, dalam konteks logika pembebasan tubuh/ emancipation of body dan pembebasan hasrat/ liberation of desire' (Piliang, 2004: 383). Yang selama ini dianggap sebagai pornografi dalam teks Crayon Shinchan adalah ulah Shinchan yang suka memperlihatkan tubuhnya terutama bagian bawah, atau fantasi-fantasi atau keinginannya untuk berkenalan dengan perempuan yang cantik dan bertubuh seksi. Contoh kejadian yang mungkin telah dianggap sebagai pornografi, misalnya Shinchan hanya mau diajak ke dokter jika dokternya cantik, dan ketika mendapatkan dokter giginya memang cantik, seksi, dan ramah ia berusaha makan coklat sebanyak-banyaknya agar dapat diajak ke dokter itu lagi; atau sehabis mandi ia justru lari-lari ke luar rumah, dan ketika ada gadis lewat ia membuka handuknya agar badannya dilihat perempuan itu. Ia mengatakan bahwa itu permainan (Cilukba) yang sering diajarkan Papa. Juga ketika disuruh belanja oleh Mamanya, ia lupa di mana telah menaruh catatan dan uang belanjanya, maka ia mencarinya dengan menaggalkan semua bajunya di toko. Jika pornografi dipahami seperti apa yang dikemukakan Piliang, maka apa yang terdapat dalam teks Shinchan bukanlah pornografi, karena teks ini tidak secara sengaja memiliki intensitas untuk menghasilkan kepuasan seksual. Menurut Elliot (1992 : 217), menggambarkan anak-anak secara seksi atau melakukan hal-hal yang seksi menimbulkan kesan 'cute' atau menggemaskan, dan ini bukan pornografi.

Teks ini memang mengandung ekspresi-ekpresi yang berorientasi bebas dan terbuka dalam hal hasrat dan pemahaman terhadap tubuh seperti yang disetujui oleh Foucault, yang barangkali bagi masyarakat Indonesia yang sejak lama menabukan keterbukaan ekspresi tubuh akan terasa norak atau jorok. Apalagi jika hal tersebut dilakukan oleh anak se usia Shinchan.

\section{H. SIMPULAN}

Dari uraian di atas, dapat dikatakan bahwa komik Crayon Shinchan sarat dengan unsur-unsur postmodern yang membuatnya bersifat problematis. Oleh karena itu jika teks ini dipandang atau dinilai dengan menggunakan kacamata modernisme, maka makna yang akan diperoleh adalah kefrustrasian, seperti apa yang terjadi pada Kepala Dinas Pendidikan Kabupaten Sleman, para pakar sastra anak dan YLKI, karena tolok ukur atau paradigma berpikir yang digunakan oleh pembaca dan teks jelas berbeda. Seperti apa yang dikatakan Ross, bahwa sekarang kita membutuhkan cara penilaian baru:

One of the great virtues of the debate over postmodern culture is that it carried forward this new kind of evaluation of the function of common culture in the modern period exactly by refusing traditional moral-aesthetic valuations (Ross, 1989 dalam Wheale, 1995:35).

Hal ini tidak berarti penilaian yang dilakukan dengan kacamata berbeda tidak bisa dilakukan, tetapi bahwa kemudian akan timbul semacam double-coded yang terjadi pada kebanyakan teks-teks postmodernisme, yakni bahwa suatu teks bisa sangat disukai sekaligus dibenci, dicari sekaligus dihindari oleh masyarakat yang plural, dan memiliki masingmasing kacamata untuk menilai sebuah teks. Keadaan yang demikian, tidak perlu menimbulkan moral panic, tetapi harus dipahami sebagai dinamika dalam suatu perubahan jaman.

Pada era postmodernisme, teks memang tidak bisa lagi dipandang sebagai medium enlightenment atau pencerahan. Ia bukanlah sumber nilai-nilai (luhur) yang 
darinya pembaca mencari acuan atau bahkan panduan untuk hidup. Akibat kepercayaan postmodernis bahwa teks tidaklah unfied, melainkan fragmented, yang mengandung problematik, maka teks dipandang bermuka banyak atau memiliki multifacets. Dengan demikian ia berpotensi mendidik, merayu, menghibur tetapi sekaligus juga menyesatkan. Maka jika teks komik Shinchan ini dibaca dengan kacamata lama, yakni kacamata yang memandang bacaan atau media sebagai sumber nilai-nilai, atau nilai-nilai luhur yang menjadi guideline, maka pembaca hanya akan menemukan nihilisme, ketidaktentuan atau bahkan penyesatan.

Sebagai teks yang berorientasi postmodernis, komik Crayon Shinchan yang problematis dan tidak black-white ini harus dibaca secara skeptis (Lubis, 2004:14) dan diletakkan pada tempatnya sebagai teks alternatif yang bagi pembaca tertentu justru merupakan bacaan yang menyegarkan dan 'menggairahkan' karena ia mampu mengajak pembaca untuk secara aktif terlibat dalam permainan teks. Kehadiran semakin banyak lagi teks-teks seperti ini jelas membutuhkan cara pemahaman baru, atau cara membaca yang sesuai dengan nature atau semesta dari teks tersebut. Dan dengan asumsi, seperti dikatakan McRobbie, bahwa pembaca bukanlah pembaca yang pasif, melainkan pembaca yang melakukan negosiasi makna, maka kekhawatiran yang berlebihan terhadap 'nasib' pembaca Crayon Shinchan tidak perlu terjadi lagi.

\section{DAFTAR PUSTAKA}

Barker, Chris. 2000. Cultural Studies: Theory and Practice. London: Sage Publications

Barthes, Roland.1968. "The Death of the Author" dalam Waugh, Patricia. Modern Literary Theory.London: Edward Arnold

Elliott, Michele. "Images of Children in Media: Soft Kiddie Porn". dalam Pornography: Women, Violences and
Civil Liberties by Itzin, Catherine (Ed). New York: Oxford University Press

Foucault, Michel.1997. Seks dan Kekuasaan. Jakarta:Gramedia Pustaka Tama

Lubis, Akhyar.2004. Masih Adakah Tempat Berpijak bagi Ilmuwan. Bogor: Akademia

McCloud, Scott.1993. Understanding Comics: The Invisible Art. USA: Kitchen Sink Press

McRobbie, Angela. 1994. Postmodernism and Popular Culture. London: Routledge

Piliang, Yaraf Amir.2004. Postrealitas. Yogyakarta:Jalasutra

Sadar, Ikhsan. 2003. "Mengungkap Keterpurukan Komik Nasional: Studi Komparasi Komik Nasional dan Asing di Indonesia". Yogyakarta: Makalah PIMNAS 2003

Sarup, Madan.1993. An Introductory Guide to Post-Structuralism and Postmodernism. New Yor: Harvester Wheatsheaf

Suherman.2002. "Kontroversi Komik Shinchan". Yogyakarta: Makalah Seminar ttg Shinchan

Wheale, Nigel. 1995. Postmodern Arts. London: Routledge

Woodward, Kathryn. 2002. Identity and Difference. London: The Open University

Gamma.2001. 'Shinchan Diprotes, Shinchan Digandrungi'. Januari 2001

\section{Karya yang dikaji:}

Usui, Yoshito. 2002. Crayon Shinchan Vol 18. Jakarta: Indorestu Pacific

Usui, Yoshito. 2000. Crayon Shinchan Vol 10. Jakarta: Indorestu Pacific

Usui, Yoshito. 2000. Crayon Shinchan Vol 4. Jakarta: Indorestu Pacific

Usui, Yoshito. 2000. Crayon Shinchan Vol 2. Jakarta: Indorestu Pacific 